\title{
The influence of environmental variables on spatial and temporal phytoplankton dissimilarity in a large shallow subtropical lake (Lake Mangueira, southern Brazil)
}

Influência das variáveis ambientais na dissimilaridade espacial e temporal do fitoplâncton em um lago subtropical raso (Lagoa Mangueira, Brasil)

Luciane Oliveira Crossetti ${ }^{1}$, Fabiana Schneck ${ }^{2}$, Lacina Maria Freitas-Teixeira ${ }^{3}$ and

David da Motta-Marques ${ }^{4}$

${ }^{1}$ Departamento de Ecologia, Instituto de Biociências, Universidade Federal do Rio Grande do Sul - UFRGS, Caixa Postal, 15007, Agronomia, CEP 91501-970, Porto Alegre, RS, Brazil e-mail: luciane.crossetti@ufrgs.br

${ }^{2}$ Instituto de Ciências Biológicas, Universidade Federal do Rio Grande - FURG, Caixa Postal 474, CEP 96203-900, Rio Grande, RS, Brazil e-mail: fabiana.schneck@gmail.com

${ }^{3}$ Instituto Federal Sul-Rio-Grandense, Campus Sapucaia do Sul, Av. Copacabana 100, Piratini, CEP 93216-120, Sapucaia do Sul, RS, Brazil e-mail: lacina@sapucaia.ifsul.edu.br

${ }^{4}$ Instituto de Pesquisas Hidráulicas, Universidade Federal do Rio Grande do Sul - UFRGS, Caixa Postal 15029, Agronomia, CEP 91501-970, Porto Alegre, RS, Brazil e-mail:dmm@iph.ufrgs.br

\begin{abstract}
Aim: The uneven distribution of organisms in aquatic ecosystems is generally attributed to environmental heterogeneity in both space and time, reflecting the occurrence of appropriate environmental conditions and the availability of resources to biological communities. The aim of this study was to understand how the dissimilarity of the phytoplankton community in a large subtropical shallow lake is related to environmental dissimilarities. Methods: Biotic and environmental data were gathered at 19 sites along the 90-km length of Lake Mangueira. Sampling was carried out quarterly during 2010 and 2011, totaling 152 sampling units. The relationship between phytoplankton dissimilarity and the dissimilarity of environmental variables was assessed by the BioEnv analysis. Major results: There is a significant relationship between phytoplankton dissimilarity and environmental dissimilarity. The model that best explained the dissimilarity of phytoplankton among the sampling units included $\mathrm{pH}$, turbidity and nitrate. Conclusions: The dissimilarity of phytoplankton was related to the dissimilarity, which were directly associated to the variability of conditions and resources in space and time in Lake Mangueira.
\end{abstract}

Keywords: BioEnv, environmental dissimilarity, community structure, spatial variability, temporal variability.

Resumo: Objetivo: A distribuição heterogênea de organismos em ecossistemas aquáticos é geralmente atribuída à heterogeneidade ambiental espacial e temporal, refletindo a existência de condiçóes ambientais apropriadas e a disponibilidade de recursos às comunidades biológicas. $\mathrm{O}$ objetivo deste estudo foi compreender como a dissimilaridade da comunidade fitoplanctônica em um grande lago raso subtropical está relacionada a dissimilaridades ambientais. Métodos: As variáveis ambientais e a comunidade fitoplanctônica foram coletadas em 19 pontos distribuídos ao longo dos 90 km de extensão da Lagoa Mangueira, trimestralmente durante 2010 e 2011, totalizando 152 unidades amostrais. A relação entre a dissimilaridade do fitoplâncton e a dissimilaridade das variáveis ambientais foi acessada pela análise BioEnv. Principais resultados: Há uma relação significativa entre a dissimilaridade na estrutura da comunidade fitoplanctônica e a dissimilaridade ambiental. O modelo que melhor explicou a dissimilaridade do fitoplâncton incluiu $\mathrm{pH}$, turbidez e nitrato. Conclusão: A dissimilaridade fitoplanctônica foi relacionada à dissimilaridade de importantes variáveis ambientais associadas à variabilidade de condiçóes e recursos no espaço e no tempo na Lagoa Mangueira.

Palavras-chave: BioEnv, dissimilaridade ambiental, estrutura de comunidades, variabilidade espacial, variabilidade temporal. 


\section{Introduction}

All biological communities vary in space and time. The degree of variability depends on physical and chemical characteristics of the habitat, its temporal stability, and on biotic interactions (Bengtsson et al., 1997). Identifying the mechanisms responsible for this variability may help to understand the processes governing the assembly of communities and the functioning of ecosystems.

Ecologists know from experience that physical and chemical variables observed in nature vary spatially and temporally (Legendre et al., 2002; Schneck et al., 2011), and biological communities may vary accordingly. Relationships between the structure of biological communities and environmental factors have been found in many studies in aquatic environments (e.g.; Melo, 2009; Haig-They et al., 2010), some of which were addressed to the phytoplankton community (e.g. Calijuri et al., 2002; Borges et al., 2008).

The structure of phytoplankton community may be related to a multitude of environmental factors, depending on the ecosystem type, latitude, and spatial and temporal scales. For instance, Schneck et al. (2011) found that the temporal variation in the structure of communities in a single subtropical reservoir was related to nutrient concentrations and water temperature. In an interconnected pond system, electrical conductivity, water transparency, $\mathrm{pH}$ and emergent macrophyte cover explained the structure of phytoplankton communities (Vanormelingen et al., 2008). On a latitudinal scale ranging from subarctic Europe to southern South America, Kosten et al. (2012) observed that water temperature was the single most important variable explaining the proportion of cyanobacteria in the composition of phytoplankton. Regarding ecosystems depth, unequal responses on phytoplankton structuring may also be found in deep and shallow lakes, mainly conditioned by the depth of the water column and the associated limnological processes, such as the mixing patterns.

In shallow lakes, environmental variability in space and time is strongly dependent on hydrodynamics (Scheffer, 1998), and may often also be associated with the presence of a littoral zone or adjacent wetlands that are densely inhabited by aquatic macrophytes (Thomaz et al., 2008). Accordingly, three of the major factors affecting the variability of phytoplankton communities in shallow lakes are variation in water level, water circulation patterns, and the presence of macrophytes. All three factors may affect many ecosystem processes, ranging from nutrient cycling and reduction of water turbulence (Pedralli and Teixeira, 2003) to the creation of refuges for many species, directly affecting the supply of resources and the conditions for phytoplankton communities (Crossetti et al., 2007; Fragoso Jr. et al., 2008; Villamagna and Murphy, 2010; Fonseca and Bicudo, 2011). Additionally, high concentration of humic acids, originated from the decomposition of plants, leads to dark-colored water, inhibiting primary production (Thomaz et al., 2001).

Studies analyzing the relationship between environmental variability on both spatial and seasonal scales and the variations in phytoplankton communities are mostly done on reservoirs and lakes (e.g. Calijuri et al., 2002; Borges et al., 2008; Rychtecký and Znachor, 2011; Schneck et al., 2011; Wu et al., 2013). Fewer studies have explored these aspects in shallow coastal lakes (Cardoso and Motta-Marques, 2004; Crossetti et al., 2013), which might present dissimilar environmental conditions in space, due to littoral zones densely inhabited by macrophytes, and in time, given the highly hydrodynamic processes driven by wind and water-level fluctuations. Here, we evaluated the role of environmental variables in affecting the dissimilarity of phytoplankton in a large shallow subtropical lake, Lake Mangueira, based on samples gathered seasonally along the entire lake. We tested the hypothesis that the dissimilarity in phytoplankton structure is positively related to environmental dissimilarity. We went further by examining which environmental variables were more correlated with phytoplankton dissimilarity. We expected that variables related to water-level fluctuations and circulation patterns and variables related to the decomposition of macrophytes (mainly nutrient concentrations and variables that affect light availability, such as turbidity, suspended solids and humic acids) are among the variables that best explain phytoplankton dissimilarity.

\section{Material and Methods}

\subsection{Study area}

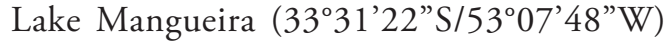
is a shallow, oligo-mesotrophic coastal lake $(\mathrm{Zmax}=6 \mathrm{~m} ; \mathrm{Zmean}=2.6 \mathrm{~m}), 90 \mathrm{~km}$ long and $3-10 \mathrm{~km}$ wide (Figure 1), located in the Taim Hydrological System, southern Brazil. The region has a subtropical climate (Cfa type; Kottek et al., 2006). The lake's main axis is northeast-southwest, aligned with the prevailing winds (Fragoso Jr. et al., 


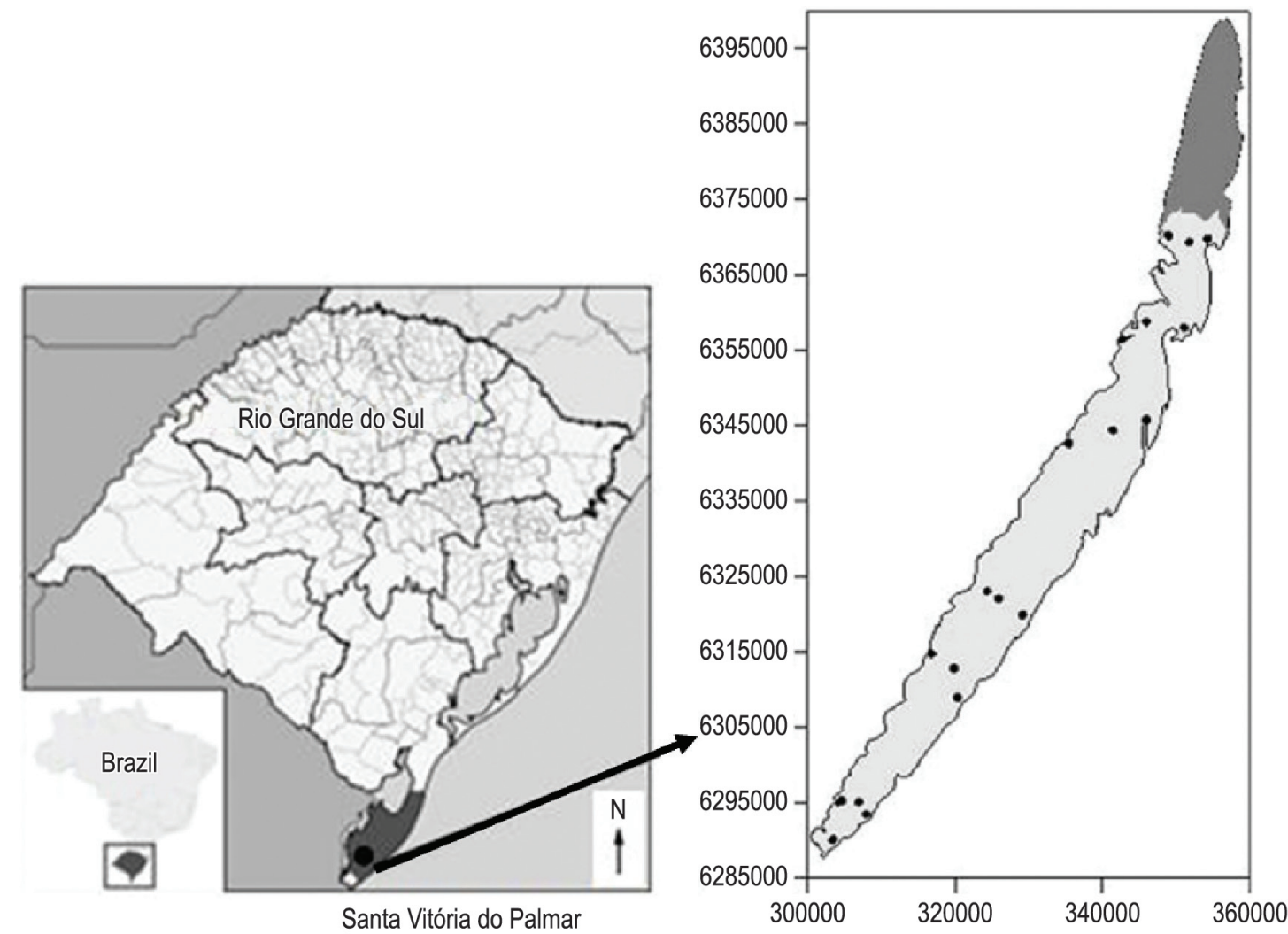

Figure 1. Location of Lake Mangueira in Santa Vitória do Palmar, state of Rio Grande do Sul, Brazil. Black circles indicate the 19 sampling points. Dark gray shading at the northern end of the lake indicates the Taim wetland.

2008). The lake is periodically drained to irrigate rice fields, which determines its hydroperiod, comprised by low-water (spring - summer) and high-water (autumn - winter) periods. The lake is influenced by a wetland at its north end, and a dense macrophyte bank at the south end. The littoral zone of the lake contains about 128 species of aquatic macrophytes (Motta-Marques et al., 2002).

\subsection{Sampling of environmental and biological variables}

Sampling was carried out at the water subsurface, seasonally (spring, summer, autumn, winter), during 2 years (2010 and 2011), at 19 sampling points along the entire lake, including the littoral and pelagic zones, totaling 152 sampling units. Environmental and biological samples were collected concomitantly.

The samples were analyzed for nutrients (soluble reactive phosphorus, total phosphorus, ammonium, nitrate, total nitrogen; Mackereth et al., 1989), soluble reactive silicon (APHA, 1992), total solids, total volatile solids, total suspended solids and total fixed solids (APHA, 1992), turbidity (turbidimeter), carbon forms, including dissolved inorganic carbon (TOC V; Shimadzu 5000), and humic acids (UV-Vis absorption measured at wavelengths of 250, 254, 365, 430 and $750 \mathrm{~nm}$ ). Water transparency (Secchi disk), water temperature, $\mathrm{pH}$, electrical conductivity and dissolved oxygen (YSI 6920 probe) were measured in situ.

Phytoplankton was counted in sedimentation chambers in an inverted microscope (Utermöhl, 1958) and sedimentation time followed Lund et al. (1958), which determined three hours for each centimeter of height of the chamber. At least 100 specimens of the most frequent species were enumerated (counting error $<5 \%$, Lund et al., 1958). Biomass $\left(\mathrm{mm}^{3} \mathrm{~L}^{-1}\right)$ was estimated through biovolume, according to Hillebrand et al. (1999).

\subsection{Data analyses}

We used the BioEnv approach (Clarke and Ainsworth, 1993; see Melo et al., 2011 for its use in beta diversity analysis) to examine the relationship between dissimilarities in community structure and dissimilarities in environmental variables. The analysis correlates dissimilarity matrices of all possible combinations of environmental variables with the biotic dissimilarity matrix and selects 
the subset of environmental variables that shows the best correlation with the biotic data. The complete environmental dissimilarity matrix was computed using Euclidean distance after centering each variable by its mean and scaling each variable by its standard deviation. After excluding highly correlated variables $(r>0.8)$, we included in the complete environmental matrix only the following variables: water transparency, $\mathrm{pH}$, electrical conductivity, dissolved oxygen, turbidity, total suspended solids, total phosphorus, soluble reactive phosphorus, total nitrogen, ammonium, nitrate, soluble reactive silicon, dissolved inorganic carbon, and humic acids measured at $365 \mathrm{~nm}$ (Table 1). The biotic dissimilarity matrix was generated using the Bray-Curtis index on log-transformed (biomass +1 ) data (Legendre and Legendre, 1998). The strength of the relationship between biotic and environmental dissimilarities was assessed through the Spearman correlation between the biotic dataset and its best environmental subset, and tested for statistical significance using a permutation procedure (with 999 permutations) implemented for Mantel tests. We conducted all analyses using the R environment (R Core Team, 2013). The BioEnv analysis and the permutation procedure were conducted using the functions bioenv and mantel available in the vegan package (Oksanen et al., 2013).

\section{Results}

A total of 117 species were identified, in seven algal classes. The most species-rich group was Chlorophyceae (48 species), followed by Cyanobacteria (41) and Bacillariophyceae (17). Cyanobacteria contributed the most biomass (89\%), followed by green algae (9\%) and diatoms
(1\%), regardless of lake zones or seasons. Chroococcus limneticus Lemmermann, Aphanocapsa conferta (West and G.S.West) Komárková-Legnerová and Cronberg and Aphanothece smithii J.KomárkováLegnerová and G.Cronberg had the highest relative biomass (2.5, 2.2 and $0.5 \mathrm{~mm}^{3} \mathrm{~L}^{-1}$, respectively), regardless of spatial or temporal variability. The mean contribution of these three species reached $77 \%$ of the total biomass.

The BioEnv analysis indicated that the environmental dissimilarity matrix that best correlated with the phytoplankton dissimilarity matrix included $\mathrm{pH}$, turbidity and nitrate $(\mathrm{r}=0.388$; Table 2). The correlation between the two matrices was significant $(\mathrm{p}<0.001)$, indicating that a large dissimilarity in the selected environmental variables among sampling units leads to a large dissimilarity in phytoplankton structure. Two other models, one including only $\mathrm{pH}$ and turbidity $(\mathrm{r}=0.3701)$ and another including $\mathrm{pH}$, turbidity, nitrate and water transparency $(r=0.3602)$ showed similar correlations to the best model (Table 2).

\section{Discussion}

We found that the dissimilarity in phytoplankton structure is significantly correlated to environmental dissimilarity. Although the distribution of phytoplankton might also be driven by several mechanisms other than local conditions and resource availability (e.g. dispersal, species strategies, biological interactions), the environmental variability may comprise much of the explanation for local community structure (e.g. Soininen et al., 2005; Vanormelingen et al., 2008). The environment inhabited by phytoplankton of large shallow lakes tends to be dissimilar at large

Table 1. Mean \pm standard deviation and minimum and maximum values of environmental variables sampled four times per year (2010 and 2011) at 19 sampling stations in Lake Mangueira, Rio Grande do Sul, Brazil.

\begin{tabular}{lcc}
\hline \multicolumn{1}{c}{ Environmental variables } & Mean \pm standard deviation & Min-Max \\
\hline Water transparency $(\mathrm{m})$ & $1.08 \pm 0.48$ & $0.34-2.73$ \\
$\mathrm{pH}$ & $7.97 \pm 0.44$ & $7.36-9.20$ \\
Electrical conductivity $\left(\mu \mathrm{S} \mathrm{cm}^{-1}\right)$ & $344 \pm 54$ & $249-485$ \\
Dissolved oxigen $\left(\mathrm{mg} \mathrm{L}^{-1}\right)$ & $0.46 \pm 0.97$ & $7.78-11.90$ \\
Turbidity $(\mathrm{NTU})$ & $21.4 \pm 15.6$ & $1.0-80.0$ \\
Total suspended solids $\left(\mathrm{mg} \mathrm{L}^{-1}\right)$ & $13.06 \pm 5.73$ & $1.5-28.0$ \\
Total phosphorus $\left(\mu \mu \mathrm{L} \mathrm{L}^{-1}\right)$ & $35.9 \pm 17.8$ & $11.6-85.2$ \\
Soluble reactive phosphorus $\left(\mu \mathrm{g} \mathrm{L}^{-1}\right)$ & $21.2 \pm 13.0$ & $1.5-56.3$ \\
Total nitrogen $\left(\mu \mathrm{g} \mathrm{L} \mathrm{L}^{-1}\right)$ & $357.5 \pm 148.7$ & $86.2-905.0$ \\
Ammonium $\left(\mu \mathrm{g} \mathrm{L} \mathrm{L}^{-1}\right)$ & $65.1 \pm 62.8$ & $2.6-348.1$ \\
Nitrate $\left(\mu \mathrm{g} \mathrm{L} \mathrm{L}^{-1}\right)$ & $102.4 \pm 71.6$ & $9.0-410.7$ \\
Soluble reactive silicon $\left(\mathrm{mg} \mathrm{L}^{-1}\right)$ & $2.82 \pm 0.62$ & $1.28-4.22$ \\
Dissolved inorganic carbon $\left(\mathrm{mg} \mathrm{L}^{-1}\right)$ & $14.47 \pm 3.87$ & $8.03-26.86$ \\
Humic acids at $365 \mathrm{~nm}$ & $0.015 \pm 0.008$ & $0.004-0.051$ \\
\hline
\end{tabular}


Table 2. Results of the BioEnv analysis for the relationship between the dissimilarity of the phytoplankton community and the dissimilarity of environmental variables in Lake Mangueira, Rio Grande do Sul, Brazil. Spearman correlation for the best model is shown in bold. Cond, electrical conductivity; DIC, dissolved inorganic carbon; DO, dissolved oxygen; $\mathrm{NH}_{3}$, ammonium; $\mathrm{NO}_{3}$, nitrate; Transp, water transparency; $\mathrm{Si}$, silicon; SRP, soluble reactive phosphorus; TN, total nitrogen; TP, total phosphorus; TSS, total suspended solids; Turb, turbidity.

\begin{tabular}{|c|c|c|}
\hline $\begin{array}{l}\text { Model } \\
\text { size }\end{array}$ & Model & Correlation \\
\hline 1 & $\mathrm{pH}$ & 0.2982 \\
\hline 2 & $\mathrm{pH}+$ Turb & 0.3701 \\
\hline 3 & $\mathrm{pH}+\mathrm{Turb}+\mathrm{NO}_{3}$ & 0.3888 \\
\hline 4 & Transp $+\mathrm{pH}+$ Turb $+\mathrm{NO}_{3}$ & 0.3602 \\
\hline 5 & Transp $+\mathrm{pH}+$ Turb $+\mathrm{TN}+\mathrm{NO}_{3}$ & 0.3376 \\
\hline 6 & Transp $+\mathrm{pH}+$ Turb $+\mathrm{TN}+\mathrm{NO}_{3}+365 \mathrm{~nm}$ & 0.3148 \\
\hline 7 & Transp $+\mathrm{pH}+$ Turb $+\mathrm{TSS}+\mathrm{TN}+\mathrm{NO}_{3}+365 \mathrm{~nm}$ & 0.2846 \\
\hline 8 & Transp + pH + DO + Turb + TSS + TN + $\mathrm{NO}_{3}+365 \mathrm{~nm}$ & 0.2275 \\
\hline 9 & Transp + pH + DO + Turb + TSS + SRP + TN + $\mathrm{NO}_{3}+365 \mathrm{~nm}$ & 0.1736 \\
\hline 10 & Transp + pH + DO + Turb + TSS + SRP + TN + $\mathrm{NH}_{3}+\mathrm{NO}_{3}+365 \mathrm{~nm}$ & 0.1231 \\
\hline 11 & Transp $+\mathrm{pH}+\mathrm{DO}+$ Turb $+\mathrm{TSS}+\mathrm{SRP}+\mathrm{TN}+\mathrm{NH}_{3}+\mathrm{NO}_{3}+\mathrm{TP}+365 \mathrm{~nm}$ & 0.0870 \\
\hline 12 & Transp $+\mathrm{pH}+\mathrm{DO}+$ Turb $+\mathrm{TSS}+\mathrm{SRP}+\mathrm{TN}+\mathrm{NH}_{3}+\mathrm{NO}_{3}+\mathrm{DIC}+\mathrm{TP}+365 \mathrm{~nm}$ & 0.0495 \\
\hline 13 & Transp $+\mathrm{pH}+$ Cond $+\mathrm{DO}+$ Turb $+\mathrm{TSS}+\mathrm{SRP}+\mathrm{TN}+\mathrm{NH}_{3}+\mathrm{NO}_{3}+\mathrm{DIC}+\mathrm{TP}+365 \mathrm{~nm}$ & 0.0208 \\
\hline 14 & Transp $+\mathrm{pH}+$ Cond $+\mathrm{DO}+$ Turb $+\mathrm{TSS}+\mathrm{SRP}+\mathrm{TN}+\mathrm{NH}_{3}+\mathrm{NO}_{3}+\mathrm{Si}+\mathrm{DIC}+\mathrm{TP}+365 \mathrm{~nm}$ & -0.0050 \\
\hline
\end{tabular}

scales (e.g. littoral and pelagic zones), and is also susceptible, at smaller scales, to the rapid changes produced by hydrodynamics. Hydrodynamics might also contribute to the dissimilarities found in large lakes in space and time, as previously shown for Lake Mangueira, in which ecosystem processes are highly dependent on wind action (see Fragoso Jr. et al., 2008).

Our hypothesis regarding which environmental variables would best explain phytoplankton dissimilarities was corroborated, since turbidity and nitrate (plus $\mathrm{pH}$ ), variables related to the lake hydrodynamics, were selected as the best subset of variables. A similar set of environmental variables, related to water-level fluctuations and wind action (nutrients, $\mathrm{pH}$, conductivity and water temperature), best explained variations in phytoplankton functional groups in Lake Mangueira in a long-term data set (six years) (Crossetti et al., 2013). The importance of the set of environmental variables selected in the present study is related to optimal environmental conditions and availability of resources found for phytoplankton development. For instance, many algae species are sensitive to changes in $\mathrm{pH}$, such as most planktic species of Cyanobacteria which do not grow at $\mathrm{pH}$ levels much below 6.0 (Reynolds, 2006). Besides, $\mathrm{pH}$ may be an indicative of different forms of carbon availability which might also influence phytoplankton structure (see Shapiro, 1973). Regarding turbidity, it affects light availability, influencing phytoplankton biomass and structure (Becker et al., 2009). Turbidity (and by consequence, low light availability) generated by daily water mixing and sediment resuspension due to wind action has already been suggested to be an important factor in determining the composition of phytoplankton communities in the Taim Hydrological System, where Lake Mangueira is located (Crossetti et al., 2007).

Dissimilarities in nitrate availability may also lead to differences in phytoplankton structure, since half-saturation concentrations for nitrate uptake may vary among phytoplankton species (Halterman and Toetz, 1984; Tilman et al., 1986). Some Cyanobacteria species, the most abundant group in Lake Mangueira, are tolerant to environments with nitrogen deficiency and are able to uptake different forms of nitrogen (Blomqvist et al., 1994; Chaffin and Bridgeman, 2014) or even to fix it (Dokulil and Teubner, 2000). In Lake Mangueira, nutrient limitation was more pronounced in the south part of the lake (not shown), where there are submerged macrophytes that may compete with phytoplankton, restricting the occurrence of algae to the best-adapted species, such as metaphytic algae (Padisák, 1992; Crossetti et al., 2013). On the other hand, Cardoso et al. (2012) reported that the wetland influence in the north part of Lake Mangueira led to higher concentrations of dissolved nutrients, especially from the decomposition of aquatic macrophytes. Additionally, the seasonal hydroperiod may affect nutrient concentrations, since limited nitrate availability might be associated with the dilution effect of high water, as shown previously by Crossetti et al. (2007) 
in Lake Mangueira and several studies in other aquatic ecosystems (e.g. Mihaljević et al., 2009; Mackay et al., 2011).

The approach used in this study is very useful for evaluating not only the existence of a correlation pattern between biotic and environmental dissimilarities, but also to find the environmental variables that best explain biotic dissimilarities. Here, we showed that the dissimilarities in phytoplankton structure of Lake Mangueira were related to environmental dissimilarities, which is directly associated to the variability of conditions and resources in space and time, especially nutrient concentrations and light availability.

\section{Acknowledgements}

We thank two anonymous reviewers for suggestions that improved the manuscript. Janet W. Reid revised the English. This study was supported by the Conselho Nacional de Desenvolvimento Científico e Tecnológico - CNPq (process 480142/2011-4).

\section{References}

American Public Health Association - APHA. 1992. Standard methods for examination of water and waste water. 18th ed. Washington. 1100 p.

BECKER, V., HUSZAR, VLM. and CROSSETTI, LO. 2009. Responses of phytoplankton functional groups to the mixing regime in a deep subtropical reservoir. Hydrobiologia, vol. 628, no. 1, p. 137-151. http://dx.doi.org/10.1007/s10750-009-9751-7

BENGTSSON, J., BAILLIE, SR. and LAWTON, J. 1997. Community variability increases with time. Oikos, vol. 78, no. 2, p. 249-256. http://dx.doi. org/10.2307/3546291

BLOMQVIST, P., PETTERSSON, A. and HYENSTRAND, P. 1994. Ammonium-nitrogen: a key regulatory factor causing dominance of nonnitrogen-fixing Cyanobacteria in aquatic systems. Archiv für Hydrobiologie, vol. 132, no. 2, p. 141-164.

BORGES, PAF., TRAIN, S. and RODRIGUES, LC. 2008. Spatial and temporal variation of phytoplankton in two subtropical Brazilian reservoirs. Hydrobiologia, vol. 607, no. 1, p. 63-74. http:// dx.doi.org/10.1007/s10750-008-9367-3

CALIJURI, MC., SANTOS, ACA. and JATI, S. 2002. Temporal changes in the Phytoplankton community structure in a tropical and eutrophic reservoir (Barra Bonita, SP, Brazil). Journal of Plankton Research, vol. 24, no. 7, p. 617-634. http://dx.doi. org/10.1093/plankt/24.7.617

CARDOSO, LS. and MOTTA-MARQUES, D. 2004. The influence of hydrodynamics on the spatial and temporal variation of phytoplankton pigments in a large, sub-tropical coastal lake (Brazil). Brazilian Archives of Biology and Technology, vol. 47, no. 4, p. 587-600. http://dx.doi.org/10.1590/S151689132004000400013

CARDOSO, LS., FRAGOSO JR., CR., SOUZA, RS. and MOTTA-MARQUES, D. 2012. Hydrodynamic control of plankton spatial and temporal heterogeneity in subtropical shallow lakes In SCHULZ, HE., SIMÕES, ALA. and LOBOSCO, RJ., eds. Hydrodynamics: natural water bodies. Rijeka: Intech Open Access Publisher. 286 p.

CHAFFIN, JD. and BRIDGEMAN, TB. 2014. Organic and inorganic nitrogen utilization by nitrogenstressed cyanobacteria during bloom conditions. Journal of Applied Phycology, vol. 26, no. 1, p. 299309. http://dx.doi.org/10.1007/s10811-013-0118-0

CLARKE, KR. and AINSWORTH, M. 1993. A method of linking multivariate community structure to environmental variables. Marine Ecology Progress Series, vol. 92, p. 205-219. http://dx.doi.org/10.3354/ meps092205

CROSSETTI, LO., BECKER, V., CARDOSO, LS., RODRIGUES, LHR., COSTA, LS. and MOTTA-MARQUES, D. 2013. Is phytoplankton functional classification a suitable tool to investigate spatial heterogeneity in a subtropical shallow lake? Limnologica, vol. 43, no. 3, p. 157-163. http://dx.doi. org/10.1016/j.limno.2012.08.010

CROSSETTI, LO., CARDOSO, LS., CALLEGARO, VLM., ALVES-DA-SILVA, SM., WERNER, VR., ROSA, ZM. and MOTTA-MARQUES, D. 2007. Influence of the hydrological changes on the phytoplankton structure and dynamics in a subtropical wetland-lake system. Acta Limnologica Brasiliensia, vol. 19, no. 3, p. 315-329.

DOKULIL, MT. andTEUBNER, K. 2000. Cyanobacterial dominance in lakes. Hydrobiologia, vol. 438, no. 1-3, p. $1-12$.

FONSECA, BM. and BICUDO, CEM. 2011. Phytoplankton seasonal and vertical variations in a tropical shallow reservoir with abundant macrophytes (Ninféias Pond, Brazil). Hydrobiologia, vol. 665, no. 1, p. 229-245. http://dx.doi.org/10.1007/s10750-0110626-3

FRAGOSO JR., CR., MOTTA-MARQUES, D., COLLISCHONN, W., TUCCI, CEM. and VAN NES, EH. 2008. Modeling spatial heterogeneity of phytoplankton in Lake Mangueira, a large shallow subtropical lake in South Brazil. Ecological Modelling, vol. 219, no. 1-2, p. 125-137. http://dx.doi. org/10.1016/j.ecolmodel.2008.08.004

HAIG-THEY, NG., MOTTA-MARQUES, D., JEPPESEN, E. and SØNDERGAARD, M. 2010. Bacterioplankton in the littoral and pelagic zones of subtropical shallow lakes. Hydrobiologia, vol. 646, 
no. 1, p. 311-326. http://dx.doi.org/10.1007/ s10750-010-0177-z

HALTERMAN, SG. and TOETZ, DW. 1984. Kinetics of nitrate uptake by freshwater algae. Hydrobiologia, vol. 114, no. 3, p. 209-214. http:// dx.doi.org/10.1007/BF00031872

HILLEBRAND, H., DÜRSEKEN, D., KIRSCHIEL, D., POLLINGHER, U. and ZOHARY, T. 1999. Biovolume calculation for pelagic and benthic microalgae. Journal of Phycology, vol. 35, no. 2, p. 403-424. http://dx.doi.org/10.1046/j.15298817.1999.3520403.x

KOSTEN, S., HUSZAR, VLM., BÉCARES, E., COSTA, LS., VAN DONK, E., HANSSON, LA., JEPPESEN, E., KRUK, C., LACEROT, G., MAZZEO, N., DE MEESTER, L., MOSS, B., LÜRLING, M., NÕGES, T., ROMO, S. and SCHEFFER, M. 2012. Warmer climates boost cyanobacterial dominance in shallow lakes. Global Change Biology, vol. 18, no. 1, p. 118-126. http:// dx.doi.org/10.1111/j.1365-2486.2011.02488.x

KOTTEK, M., GRIESER, J., BECK, C., RUDOLF, B. and RUBEL, F. 2006. World Map of the KöppenGeiger climate classification updated. Meteorologische Zeitschrift, vol. 15, no. 3, p. 259-263. http://dx.doi. org/10.1127/0941-2948/2006/0130

LEGENDRE, P. and LEGENDRE, L. 1998. Numerical ecology. Amsterdam: Elsevier. 853 p.

LEGENDRE, P., DALE, MRT., FORTIN, MJ., GUREVITCH, J., HOHN, M. and MYERS, D. 2002. The consequences of spatial structure for the design and analysis of ecological field surveys. Ecography, vol. 25, no. 5, p. 601-615. http://dx.doi. org/10.1034/j.1600-0587.2002.250508.x

LUND, JWG., KIPLING, C. and LECREN, ED. 1958. The inverted microscope method of estimating algal numbers and the statistical basis of estimations by counting. Hydrobiologia, vol. 11, no. 2, p. 143-170. http://dx.doi.org/10.1007/BF00007865

MACKAY, EB., JONES, ID., FOLKARD, AM. and THACKERAY, SJ. 2011. Transition zones in small lakes: the importance of dilution and biological uptake on lake-wide heterogeneity. Hydrobiologia, vol. 678, no. 1, p. 85-97. http://dx.doi.org/10.1007/ s10750-011-0825-y

MACKERETH, FJH., HERON, J. and TALLING, JF. 1989. Water analysis: some revised methods for limnologists. Ambleside: Freshwater Biological Association. 120 p. Scientific Publication no. 36.

MELO, AS. 2009. Explaining dissimilarities in macroinvertebrate assemblages among stream sites using environmental variables. Zoologia, vol. 26, no. 1, p. 79-84.

MELO, AS., SCHNECK, F., HEPP, LU., SIMŌES, NR., SIQUEIRA, T. and BINI, LM. 2011. Focusing on variation: methods and applications of the concept of beta diversity in aquatic ecosystems. Acta Limnologica Brasiliensia, vol. 23, no. 3, p. 318-331. http://dx.doi. org/10.1590/S2179-975X2012005000010

MIHALJEVIĆ, M., STEVIĆ, F., HORVATIĆ, J. and KUTUZOVIĆ, BH. 2009. Dual impact of the flood pulses on the phytoplankton assemblages in a Danubian floodplain lake ((Kopački Rit Nature Park, Croatia). Hydrobiologia, vol. 618, no. 1, p. 7788. http://dx.doi.org/10.1007/s10750-008-9550-6

MOTTA-MARQUES, D., TUCCI, C., CALAZANS, D., CALLEGARO, VLM. and VILLANUEVA, A. 2002. O sistema hidrológico do Taim: site 7. In SEELIGER, U., CORDAZZO, CV. and BARBOSA, F., eds. Os sites e o Programa Brasileiro de Pesquisas Ecológicas de Longa Duração. Belo Horizonte: MCT/ CNPq. $184 \mathrm{p}$.

OKSANEN, J., BLANCHET, FG., KINDT, R., LEGENDRE, P., MINCHIN, PR., O'HARA, RB., SIMPSON, GL., SOLYMOS, P., STEVENS, MHH. and WAGNER, H. 2013. Vegan: community ecology package. R package version 2.0-7. Available from: $<$ http://CRAN.R-project.org/package=vegan>.

PADISÁK, J. 1992. Seasonal succession of phytoplankton in a large shallow lake (Balaton, Hungary): a dynamic approach to ecological memory, its possible role and mechanisms. Journal of Ecology, vol. 80, no. 2, p. 217230. http://dx.doi.org/10.2307/2261008

PEDRALLI, G. and TEIXEIRA, MCB. 2003. Macrófitas aquáticas como agentes filtradores de materiais particulados, sedimentos e nutrientes. In HENRY, R., ed. Ecótonos nas interfaces dos ecossistemas aquáticos. São Carlos: Rima. 349 p.

R Core Team. 2013. $R$ : a language and environment for statistical computing. Vienna: R Foundation for Statistical Computing. Available from: <http:// www.R-project.org/>.

REYNOLDS, CS. 2006. The ecology of phytoplankton: ecology, biodiversity and conservation. Cambridge: Cambridge University Press. 535 p.

RYCHTECKÝ, P. and ZNACHOR, P. 2011 Spatial heterogeneity and seasonal succession of phytoplankton along the longitudinal gradient in a eutrophic reservoir. Hydrobiologia, vol. 663, no. 1, p. 175-186. http://dx.doi.org/10.1007/s10750010-0571-6

SCHEFFER, M. 1998. Ecology of shallow lakes. London: Chapman \& Hall. 357 p.

SCHNECK, F., SCHWARZBOLD, A., RODRIGUES, SC. and MELO, AS. 2011. Environmental variability drives phytoplankton assemblage persistence in a subtropical reservoir. Austral Ecology, vol. 36, no. 7, p. 839-848. http://dx.doi.org/10.1111/j.14429993.2010.02224.x

SHAPIRO, J. 1973. Blue-green algae: why they become dominant. Science, vol. 179 , no. 4071 , p. 382- 
384. PMid:4630211. http://dx.doi.org/10.1126/ science. 179.4071 .382

SOININEN, J., TALLBERG, P. and HORPPILA, J. 2005. Phytoplankton community assembly in a large boreal lake: deterministic pathways or chaotic fluctuations? Freshwater Biology, vol. 50, no. 12, p. 2076-2086. http://dx.doi.org/10.1111/j.13652427.2005.01459.x

TILMAN, D., KIESLING, R., STERNER, R., KILHAM, SS. and JOHNSON, F. A. 1986. Green, bluegreen and diatom algae: taxonomic differences in competitive ability for phosphorus, silicon and nitrogen. Archiv für Hydrobiologie, vol. 106, no. 4, p. 473-485.

THOMAZ, SM., ENRICH-PRAST, A., GONÇALVES, JF., SANTOS, AM. and ESTEVES, FA. 2001. Metabolism and gaseous exchanges in two coastal lagoons from Rio de Janeiro with distinct limnological characteristics. Brazilian Archives of Biology and Technology, vol. 44, no. 3, p. 433-438.

THOMAZ, SM., DIBBLE, ED., EVANGELISTA, LR., HIGUTI, J. and BINI, LM. 2008. Influence of aquatic macrophyte habitat complexity on invertebrate abundance and richness in tropical lagoons. Freshwater Biology, vol. 53, no. 2, p. 358367.

UTERMÖHL, H. 1958. Zur Vervolkomnung der quantitativen Phytoplankton-Methodik. Mitteilungen der Internationale Vereinigung für Theoretische und Angewandte Limnologie, vol. 9, p. 1-38.

VANORMELINGEN, P., COTTENIE, K., MICHELS, E., MUYLAERT, K., VYVERMAN, W. and DE MEESTER, L. 2008. The relative importance of dispersal and local processes in structuring phytoplankton communities in a set of highly interconnected ponds. Freshwater Biology, vol. 53, no. 11 , p. 2170-2183.

VILLAMAGNA, AM. and MURPHY, BR. 2010. Ecological and socio-economic impacts of invasive water hyacinth (Eichhornia crassipes): a review. Freshwater Biology, vol. 55, no. 2, p. 282-298. http:// dx.doi.org/10.1111/j.1365-2427.2009.02294.x

WU, Z., CAIA, Y., LIU, X., XU, CP., CHEN, Y. and ZHANG, L. 2013. Temporal and spatial variability of phytoplankton in Lake Poyang: the largest freshwater lake in China. Journal of Great Lakes Research, vol. 39, no. 3, p. 476-483. http://dx.doi.org/10.1016/j. jglr.2013.06.008 